\title{
THE SOCIAL MARKETING MANAGEMENT AND QUALITY OF THE TOURIST PRODUCT
}

UDK: 338.486

Received: 2nd May, 1996

Preliminary report

\begin{abstract}
Quality and uniform marketing goals concerned to tourist enterprise, client and society. Three ways of marketing goals in tourist development countries: product, destination, satisfaction of the clients needs. Successful quality apply is possible if there are: existence and applicability of general norms of products quality, creativity of the special standards. Existence and aplication experiences of the standards in Slovakia. Difficulties in the area of social problems. Claim to cooperation of tourist enterprises, state and regional institutions. The main problems is our society: environment, security of the life and healthy, protection of cultural heritage. Proposal of possible solutions.
\end{abstract}

Key words: social marketing management, quality of tourist product, tourist enterprise, satisfaction of clients needs, general norms, standards, manuals, society, environment, security, protection of cultural heritage

\section{INTRODUCTION} evident.

The influence of social marketing management to quality of tourist product is

Several social problems defend to create high level of tourist product quality. Usually we seek the "social responsibility" of tourist enterprises. Is only this way to apply the social marketing management?

\section{THE QUALITY IS VERY IMPORTANT FACTOR OF THE BUSINESS SUCCESS}

This factor creates competition ability of enterprises.

By marketing experts "the quality is not only problem necessary to solve, but it is the competition's opportunity: 1)

This idea express the filosofy of marketing management, which pay very great attention to quality and it seems this one as it's indivisible part.

The theory recomands to lay stress upon the (partly) uniform marketing goals concerned to tourist enterprise, client and society. 2) 


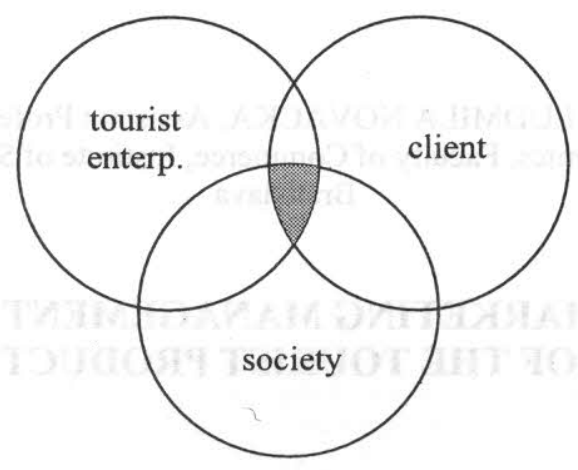

The Total Quality Management identify this attention to all management functions and this fact is obvious in the production process of products and services, too.

The main attention is given to marketing control. It consists of two complementary activities: strategic control, which is concerned with "doing the right things" and operations control, which focuses on "doing things right".3)

The tourist product as a package presents synchronize utilization of material and nonmaterial sources with the aim - to satisfy the tourist needs and demand.4)

It is known, that to survey for the quality of material products is not so complicate. In the practice, there exists the quality norms, wchich names require very exactly and these requirements is possible to measure or quantify.

The quality in the services is present as a difference between the sold service and the service, which was awaited by client.5)

The marketing theory and also practice in the tourist development countries shows three ways of marketing goals in the tourism field:
a) product
b) destination
c) satisfaction of the clients needs.

I think that all three types of marketing orientation they fulfill the quality require. But only the third way, wchich is presented by satisfaction of the needs fully cover the idea of quality.

This is the reason, why is very important within the framework of services in the tourism area not only "what" I offer to my client, but " how" I offer my tourist product. follow:

The Total Quality Management process in the tourist product we can suggest 
the preparation of services

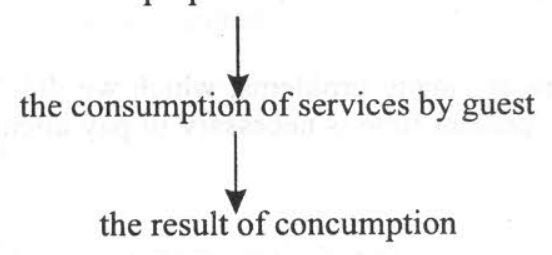

Succesful quality apply during all named phases is possible only in the case, if there are these main assumptions:

1. the existence and applicability of general norms of products quality, which participate in the production chain of tourist subproducts (f.ex. the meat or the beer at the food and beverage, the water in swimming pool, air condition in the bus, etc.)

2.the creativity of the special quality norms ( standards) which are valid

a) for several types of tourist products or

b) for individual tourist enterprises = manuals (f. ex. services in the air-companies, in the franchising hotels or restaurants etc.).

All standards and manuals we can find in Slovakia, too.

Within the first group of general norms, Slovakia is developing slowly as in the countries of European Union, but the management of quality utilize similar approach, by way of accepting ISO 9000-9004.

Within the framework of the second group I have to mention, that in Slovakia, there are special standards on the level of acts. (F. ex. "Categorisation" 6) of hospitality or categorisation of accomodation services 7),too. This new act is very strong, for major number of slovak hotels it require investment costs. This act is not not popular between enterprineuers. Managers, they seek to change this standard or to keep some special individual exceptions.

In the bus transport, the bus companies in Slovakia, they started to use and aply international categorisation of International Road and Travel Union . But this norm is not obligatory in present time.

All indicated groups of standards are usualy create on the base of longtime experiences and they could accept the main needs of the guests.

By comparative way of these two groups of norms and standars, is clear and I can say too, that the second group presented by quality standards and manuals they can achieve quality aim faster and more perfectly.

This mentioned require (with bigger or small problems) is possible to keep in every tourist enterprise.

For every tourist enterprise is very complicate and it's influence is very difficult in the area of social problems.

The tourist enterprise is able degrade (bring down) the effects of the social problems only partly, but it cannot do solution in principle. 
It is the reason, why is necessary cooperation of the state and regional institutions in this field.

In our society, there are many problems, which we didn't know before so much. My opinion is that in the present time is necessary to pay attention mainly to following problems:

\section{a) Environment}

- pollution and decreasing of its quality by industry, traffic, agriculture and the task of protection of environment on the one hand, and on the other hand

- influence of mass tourism and the task of sustainable tourism and very responsive utilisation of nature, recreational space.

Within the framework of environmental quality the first big chemical industrial company (Matador Puchov ), they did obtain certificate on the base of quality norms ISO 14000, ISO/DIS 14001 and BS 7750.

This is the first nice example of the protection on the international level. We know, that in Slovakia, there are regions with very good quality of the air, water and earth, but we can find the space with high level of pollution. Under the document of Slovak Ministry of Environment, in Slovakia there are 12 regions, where is environment very polluted by chemical, iron and energy industry. 8)

The tourist enterprises cannot change this situation. The industrial factories (factories in the state property and ones in the private property also), usually haven't capital for new ecological investment and very often they do not pay the fine.

Certain new way of social (state) help is presented by new Strategy, principles and priorities of the state enviromental policy.9)

The protection of landscape and nature is proclamed by the act 10). It aims to prevent and restrict destructive interference to nature or its ecological stability and to remove any consequences of this interference. The act recognises five categories of protected landscape.

b) security of the life and healthy, safety of tourists property in every daily or nightly time, not only within the tourist enterprise area (hotel, bus or tourist centre), but in the teritory of whole country. The high level of crimes, the new transport ways of droggs, prostitution they did not decrease, yet.

c) the protection of cultural heritage. In Slovakia the Ministry of Culture, the District and the local Civil Service and municipal institutions may declare the cultural heritage of three quality levels.11) The owner of a heritage site are mainly responsible for the care and protection of the cultural heritage and it is their duty to pay all costs. User of heritage site participate in these costs within a framework of agreement between him and owner. If the owner wish to repair, reconstruct or to restore the heritage, he has "report duty" and he must adhere to the requirements of appointed state institutions which help owner by providing advice and information from expert consultants. These advices of several institutions (the Heritage insitute, Building offices and Cartography offices) has the form of order very often. It is from the point of care for heritage very good, but from the point of utilization it presents very often barriers. 
In cases where costs are high owners can obtain a grant from the Ministry of Finance. Such grants are, of course, limited.

\section{CONCLUSION}

What can we do? The theory recomands and to lay stress upon the (partly) uniform marketing goals concerned to enterprise, clients and society.

They reside in the social goals by acceptance of social marketing. But on the other hand in the society exists the social problems, which is impossible to solve without cooperation of the tourist enterprices, regional and governmental institutions.

It require mainly:

- the identification of target social marketing goals

- providing an appropriate macroeconomic policy, legal-regulatory and institutional environment and creating the conditions to attain ambitions of the named goals

- pilot projects of this goals

- providing consultancy in preparing feasibility studies, operational and training manuals assistance in recruiting social marketing goals

- stimulating the banking sector to develop appropriate credit facilities - cooperation between governmental institutions on the field of similar social marketing problems.

\section{LITERATURE}

\section{OUOTATIONS:}

1) Kotler Ph., Armstrong G.: Marketing, SPN Bratislava, 1992, p.197

2) Novacka L.: Marketingovl management podnikov cestovneho ruchu, Elita Bratislava, 1993, str. 9

3) Kerin R.A.,Peterson R.A.: Strategic Marketing Problems, Allyn and Bacon USA, 1990, p. 543

4) Novacka L., Kulcakova M.: Klient v cestovnom ruchu, Eurounion Bratislava, 1996, p. 10

5) Heskett J.1., Sasser W.E., Hart Ch.W.L.: Sluzby: cesta k uspechu, Victoria Publishing Praha, 1993, p. 112

6,7) Act: Vyhlaska MH SR c. 125/1995 Zb.

8,9) Trend, 22/1996, Section A, p. 8 ,

10) The Act of NCoS N. $24 / 1987$ Zb.recognises quality level in Slovakia: National Parks (5),Protected Landscapes Region (16), Natural Reservation (311), Protected Areas and Natural Heritage Sites.

11) Act of the National Council of Slovakia N. 274/1994 Zb., recognises these quality level: National Cultural Heritage, Heritage Reservations, Heritage Zones. 
Sažetak

\section{DRUŠTVENI MARKETING MANAGEMENT I KVALITETA TURISTIČKOG PROIZVODA}

Kvaliteta i jedinstveni marketinški ciljevi se razmatraju u svezi s turistickim poslovanjem, gostima i društvom. Marketinški ciljevi se ostvaruju u turističkim zemljama u razvoju putem: proizvoda, destinacije, zadovoljenja želja gosta. Uspješna primjena kvalitete se može postići ako postoje i ako su primjenjive opće norme za kvalitetu proizvoda i kreativnost općih standarda. Prikazana su iskustva sa standardima koji postoje i koji su primjenjivi u Slovackoj. Dat je prikaz problema u društvenom području. Zahtijeva se suradnja između turistickih poduzeća, države i regionalnih institucija. Glavni problemi u našem društvu: okruženje, sigurnost života i zdravlja, zaštita kulturnog nasljeđa. Predlažu se moguća rješenja.

Ključne riječi društveni marketing management, kvaliteta turističkih proizvoda, turistið̌ko poslovanje, zadovoljenje želja gostiju, opće norme, standardi, društvo, okruženje, sigurnost, zaštita kulturnog nasljeđa 